\title{
Antibiotic resistance profiles in cultivable microbiota isolated from some romanian natural fishery lakes included in Natura 2000 network
}

Veronica Lazăr ${ }^{1,2,3}$, Irina Gheorghe ${ }^{1,2^{*}}$, Carmen Curutiu ${ }^{1,2+}$, Ioana Savin ${ }^{4}$, Florica Marinescu ${ }^{1,2,4}$, Violeta Corina Cristea ${ }^{1,2,5}$, Dumitru Dobre ${ }^{3}$, Gabriela Loredana Popa ${ }^{5,6}$, Mariana Carmen Chifiriuc ${ }^{1,2,7+}$ and Mircea loan Popa ${ }^{5,6}$

\begin{abstract}
Background: The present study aims the characterization of antibiotic resistance phenotypes and encoding genes in bacterial strains isolated from some Romanian aquatic fishery lowland salted lakes.

Material/Methods: This study was conducted on 44 bacterial strains, mainly belonging to species used as microbiological indicators of fecal pollution isolated from four natural fishery lakes. All strains were tested for their antibiotic susceptibility by disk diffusion method. Simplex and multiplex PCR were performed to identify the $\beta$ lactams antibiotic resistance genes (bla $a_{\mathrm{NMD}}$, bla $\left.a_{\mathrm{OXA}-48}, b / a_{\mathrm{VIM}}, b / a_{\mathrm{IMP}}, b / a_{\mathrm{CTX}-\mathrm{M}}, b / a_{\mathrm{TEM}}\right)$, sulfonamides (Sul1, Sul2), tetracyclines (TetA, TetB, TetC, TetD, TetM), aminoglycosides (aac3la), vancomycin (VanA, VanB, VanC), macrolides (ermA, ermB, ermC) as well as the plasmid-mediated quinolone resistance (PMQR) markers (QnrA, QnrB, QnrS), and class 1 integrons (Int1, drfA1-aadA1).

Results: The Enterococcus spp. isolates exhibited phenotypic resistance to vancomycin (35\%) and macrolides (erythromycin) (75\%); from the vancomycin - resistant strains, $5 \%$ harboured VanA (E. faecalis), while the erythromycin resistant isolates were positive for the ermA gene (E. faecalis - $10 \%$, E. faecium - $5 \%$ ). The Gramnegative rods (GNR) exhibited a high level of resistance to $\beta$-lactams: cefuroxime (63\%), cefazolin (42\%), ceftriaxone $(8 \%)$, ceftazidime and aztreonam ( $4 \%$ each). The genetic determinants for beta-lactam resistance were represented by bla $a_{\mathrm{CTX}-\mathrm{M} \text {-like }}(33 \%)$, bla $a_{\mathrm{NDM}-\text { like }}$ and bla IMP-like $(8.33 \%)$ genes. The resistance to non- $\beta$-lactam antibiotics was ascertained to the following genes: quinolones (QnrS - 4.16\%); sulfonamides (Sul1-75\%, Sul2-4.16\%); aminoglycosides (aac3la $-4.16 \%$ ); tetracyclines (tetA $-25 \%$, tetC $-15 \%$ ). The integrase gene was found in more than $50 \%$ of the studied strains (58.33\%).

(Continued on next page)
\end{abstract}

\footnotetext{
*Correspondence: iryna_84@yahoo.com

${ }^{\dagger}$ Carmen Curutiu and Mariana Carmen Chifiriuc contributed equally to this manuscript.

'Department of Microbiology and Immunology, Faculty of Biology, University of Bucharest, Bucharest, Romania

${ }^{2}$ Research Institute of the University of Bucharest (ICUB), Bucharest, Romania

Full list of author information is available at the end of the article
}

C C The Author(s). 2021 Open Access This article is licensed under a Creative Commons Attribution 4.0 International License, which permits use, sharing, adaptation, distribution and reproduction in any medium or format, as long as you give appropriate credit to the original author(s) and the source, provide a link to the Creative Commons licence, and indicate if changes were made. The images or other third party material in this article are included in the article's Creative Commons licence, unless indicated otherwise in a credit line to the material. If material is not included in the article's Creative Commons licence and your intended use is not permitted by statutory regulation or exceeds the permitted use, you will need to obtain permission directly from the copyright holder. To view a copy of this licence, visit http://creativecommons.org/licenses/by/4.0/ The Creative Commons Public Domain Dedication waiver (http://creativecommons.org/publicdomain/zero/1.0/) applies to the data made available in this article, unless otherwise stated in a credit line to the data. 


\begin{abstract}
(Continued from previous page)
Conclusions: The cultivable aquatic microbiota from fishery lakes is dominated by enterococci and Enterobacterales strains. The GNR strains exhibited high levels of $\beta$-lactam resistance mediated by extended spectrum betalactamases and metallo- $\beta$-lactamases. The Enterococcus sp. isolates were highly resistant to macrolides and vancomycin. The high level and diversity of resistance markers, correlated with a high frequency of integrons is suggesting that this environment could act as an important reservoir of antibiotic resistance genes with a great probability to be horizontally transmitted to other associated species from the aquatic sediments microbiota, raising the potential zoonotic risk for fish consumers.
\end{abstract}

Keywords: Lowland fishery lakes, Antimicrobial resistance, Enterococcus sp., Enterobacterales

\section{Background}

Antimicrobial resistance (AR) is an increasing worldwide concern, as antibiotics still represent a very important option for human and animal health protection [1]. It is expected that the mortality rates due to AR will reach as many as 10 million people/year by 2050, if appropriate action is not taken [2]. AR is now considered without any doubt a typical One Health problem, the environment having a crucial role as a reservoir and transmission route to humans. Consequently, one of the main priorities of the Joint Programme Initiative on Antimicrobial Resistance (JPIAMR) is to foster the research of environmental AR reservoirs, which are very poorly known, in comparison with clinical ones [3-6]. In 2014, Romania reported for the first time to ESVAC the consumption of veterinary antimicrobial agents [7]. At the top of the most-solded classes were tetracyclines, penicillins and aminoglycosides. Similarly, in 2016, the most consumed classes for food-producing animals in Romania according ESVAC were tetracyclines, penicillins, macrolides and aminoglycosides [8]. As antibiotics are one of the most popular pharmaceuticals used in medicine, veterinary care, and farming $[9,10]$, they can be released, most of them unchanged, into the environment. They appear as contaminants of the water bodies, especially those frequently impacted by anthropogenic activities (e.g., wastewater, municipal sewage, influents and effluents of wastewater treatment plants) [11], which have been suggested to be ideal reservoirs and vectors for the AR origin, evolution and spread [12-14]. In wastewater effluents, lakes, rivers or streams, bacteria from different sources, probably selected by intensive antibiotic usage, are collected and mixed with environmental strains, which on their turn, could introduce the newly acquired antibiotic resistance genes (ARGs) into the clinics [15-17].

Enterococci and Enterobacterales species were found in high concentrations in human and animal faeces, so their presence in any type of waters indicate the faecal contamination of the respective water body. The presence of Enterobacterales (which do not survive in the water for a long time) indicates a recent faecal water pollution with potentially pathogenic microorganisms originating from anthropogenic systems (household wastewater, livestock), but also with allochtonous species originating from natural ecosystems; enterococci can survive longer in water, due to their high resistance to physical, chemical and biological agents, indicating a chronic faecal contamination of the water [18].

These commensal intestinal bacteria could often act as reservoirs for AR determinants [19]. Therefore, the evaluation of AR profiles of these microbiological indicators of water quality could predict for the ARGs disemination from humans and animals into the environment and the risk of horizontal gene transfer (HGT) to native species.

On the other hand, AR has been detected in different aquatic environments and some resistance determinants, such as the recently emerging plasmid-mediated quinolone resistance determinants (PMQR) from the Qnr family [20] and CTX-M [21] from aquatic Kluyvera sp. have been found to originate from aquatic bacteria.

In aquaculture, antibiotics are given as a component of their food, and occasionally in baths and injections [22]. The unconsumed food, as well as the fish faeces, containing antibiotics reach the sediment and the antibiotics could be ingested by wild fish and other organisms, consequently altering the composition of the acquatic microbiota, selecting antibiotic-resistant bacteria (ARB) and favoring the HGT of ARGs [22, 23]. In this study we have investigated the Balta Albă-Amara-Jirlău-Lacul Sărat Câineni lakes, whose vulnerability resides in the spillage of household waste, significant floods and consecutive natural (Buzău river's flood) and artificial (due to fish farming activities) changes of water composition $[24,25]$. These aquatic environments were scarcely studied, the few previous studies focusing on the study of halophilic microorganisms (bacteria and arhaea), phytoplankton and zooplankton species, as well as on the organic compounds hydrolythic activity of the acquatic microbiota isolated from Amara, Balta Albă, Movila Miresei salted lakes and from Ocnele Mari area, in relation with the physical-chemical parameters $(\mathrm{pH}$, density and chloride content) of the respective waters $[26,27]$. 
Our group has previously evaluated the physicochemical and microbiological characteristics of Balta Albă-Amara-Jirlău-Lacul Sărat Câineni site included in Natura 2000 Network for establishing the degree of organic pollution and generating the knowledge required for the design and implementation of appropriate measures for maintaining the balance between the water protection and the sustainable use of these protected ecosystems [28]. By this present work, we will complete the knowledge with data regarding the most prevalent $A R B$ and ARGs present in these natural lakes. In this context, the aim of this study was to isolate and characterize the AR phenotypes (disk diffusion method) and ARGs (PCR method) in Enterococcus sp. and Gramnegative rods (mainly Enterobacterales) strains isolated in 2016 from Romanian aquatic fishery lowland salted lakes included in Natura 2000 Network [28], in the first attempt to evaluate their contribution to the AR aquatic reservoir.

\section{Results}

The isolated strains were represented by 20 Gram positive cocci and 24 Gram negative rods which have been identified using the MALDI TOF MS, as: Enterococcus faecium $(n=8)$, E. faecalis $(n=7)$, E. mundtii $(n=2), E$. casseliflavus $(n=3)$, Escherichia coli $(n=9)$, Enterobacter cloacae $(\mathrm{n}=2)$ and one strain of each of the following species: Klebsiella pneumoniae, K. oxytoca, E. kobei, E. ludwigii, E. cowanii, Escherichia hermannii, Serratia marcescens, S. rubidaea, Hafnia alvei, Pantoea ananatis, Raoultella ornithinolytica, Acinetobacter calcaoceticus. The Enterococcus spp. strains have been isolated with different frequencies, depending on the isolation sources, i.e.: E. faecalis represented $20 \%$ of the isolated strains and E. faecium only $5 \%$ in Balta Albă lake (Table 1 ); $E$. faecium strains were isolated in proportion of $15 \%$ from Câineni and Amara lakes, while from Jirlău lake $E$. mundtii and $E$. casseliflavus strains represented each $10 \%$ of the isolated enterococci and E. faecium strains only $5 \%$ (Table 1 ).

In our study, the disk diffusion susceptibility assay results revealed different resistance rates among the isolated Enterococcus spp. strains (Fig. 1).

The molecular support of the AR for all the strains isolated from fishery lakes was determined using simplex and multiplex PCR performed on genomic DNA in order to identify the genes encoding for resistance to $\beta$ lactams $\left(b l a_{\mathrm{NMD}}, b l a_{\mathrm{OXA}-48}, b l a_{\mathrm{VIM}-2}, b l a_{\mathrm{IMP}}, b l a_{\mathrm{CTX}-\mathrm{M}}\right.$, $\left.b l a_{\mathrm{TEM}}\right), \mathrm{PMQR}$ markers (QnrA, QnrB, QnrS), sulfonamides (Sul1, Sul2), tetracyclines (TetA, TetB, TetC,

Table 1 The antibiotic resistance genes and antibiotic susceptibility profiles in the analyzed Enterococcus strains distributed by the isolation sources

\begin{tabular}{|c|c|c|c|c|c|c|c|c|c|c|}
\hline \multirow[t]{2}{*}{ Strain code } & \multirow[t]{2}{*}{ Species } & \multirow[t]{2}{*}{ Isolation source } & \multicolumn{3}{|c|}{ ARGs } & \multicolumn{5}{|c|}{ Antibiotic resistance profiles } \\
\hline & & & Int & VanA & $\operatorname{erm} A$ & $\mathrm{E}$ & VA & TE & DXT & LZD \\
\hline P1 1.1 & E. faecalis & Balta Albă & $x$ & & & $x$ & $x$ & & & \\
\hline P1 1.2 & E. faecalis & Balta Albă & $x$ & & $x$ & $x$ & & $x$ & & \\
\hline P1 1.3 & E. faecalis & Balta Albă & $x$ & & & $x$ & & $x$ & $x$ & \\
\hline P1 1.4 & E. faecalis & Balta Albă & $x$ & & & $x$ & & & & \\
\hline P1 1.5 & E. faecium & Balta Albă & & & & & & & & \\
\hline P2 2.1 & E. mundtii & Jirlău & $x$ & & & $x$ & $x$ & & & \\
\hline P2 2.2 & E. casseliflavus & Jirlău & $x$ & & & & & & & $x$ \\
\hline P2 2.3 & E. mundtii & Jirlău & $x$ & & & $x$ & $x$ & & & \\
\hline P2 2.4 & E. casseliflavus & Jirlău & $x$ & & & $x$ & & $x$ & & \\
\hline P2 2.5 & E. faecium & Jirlău & $x$ & & & $x$ & & & & \\
\hline P3 3.1 & E. faecium & Câineni & $x$ & & & $x$ & & & & \\
\hline P3 3.2 & E. faecium & Câineni & $x$ & & & $x$ & $x$ & & & \\
\hline P3 3.3 & E. casseliflavus & Câineni & $x$ & & & $x$ & & & & \\
\hline P3 3.4 & E. faecium & Câineni & $x$ & & & $x$ & $x$ & & & \\
\hline P3 3.5 & E. faecalis & Câineni & $x$ & $x$ & $x$ & $x$ & $x$ & & & \\
\hline P4 4.1 & E. faecium & Amara & $x$ & & $x$ & & & & & \\
\hline P4 4.2 & E. faecium & Amara & $x$ & & & & $x$ & & & \\
\hline P4 4.3 & E. faecium & Amara & $x$ & & & $x$ & & & & \\
\hline P4 4.4 & E. faecalis & Amara & $x$ & & & $x$ & & & & \\
\hline P4 4.5 & E. faecalis & Amara & $x$ & & & & & & & \\
\hline
\end{tabular}




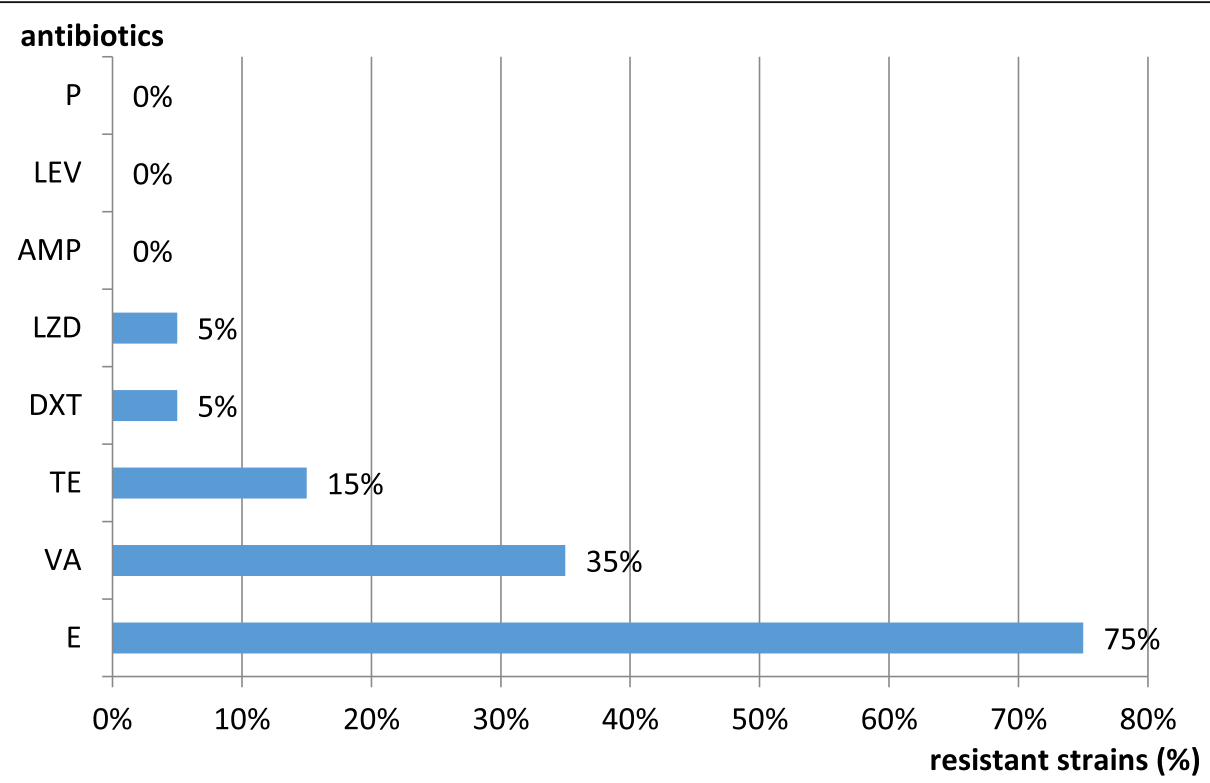

Fig. 1 The antibiotic resistance profile of the Enterococcus spp. isolated strains revealed that $75 \%$ of the strains were resistant to erythromycin, followed by vancomycin (35\%) and tetracycline (15\%), and $5 \%$ of them to doxycycline and linezolid. Ampicillin and penicillin, the most active $\beta$ lactam antibiotics against enterococci were found to be $100 \%$ efficient against isolated strains, as well as the tested fluoroquinolone (levofloxacin)

TetD, TetM), aminoglycosides (aac3Ia), vancomycin (VanA, VanB, VanC), macrolides (ermA, ermB, ermC) and class 1 integrons (Int1, drfA1-aadA1). The molecular screening results were well correlated with the phenotypic assays, revealing the presence of VanA $(E$. faecalis-5\%) in vancomycin and of ermA genes (E. faecalis $-10 \%$, E. faecium $-5 \%$ ) in erythromycin resistant isolates (Table 1).

The distribution of the isolated GNR strains by the isolation sources revealed the following aspects: in Jirlău lake $E$. coli represented $16.66 \%$ of the isolated strains followed by E. cloacae (8.33\%), E. ludwigii and A. calcoaceticus $(4.16 \%$ each) (Table 2$)$. In the salty lake $E$. coli strains were predominant $(16.66 \%)$, followed by $R$. ornithinolytica and E. hermannii (4.16\% each). In Balta Albă lake there have been identified four different species and a high diversity have been observed also in Amara lake (Table 2).

The analysed GNR strains expressed different resistance levels to $\beta$-lactam, aminoglycoside, tetracycline and trimethoprim/sulfamethoxazole antibiotics (Fig. 2).

Although some strains were resistant to antibiotics from different classes, they still remained sensitive to cephalosporins. This does not apply in case of the isolated Acinetobacter calcoaceticus strain, that proved to be resistant to all tested beta-lactams (data not shown).

The molecular study of the ARGs in the GNR strains revealed the presence of bla $a_{\mathrm{CTX}-\mathrm{M}-}$ like $(33 \%)$, bla $a_{\mathrm{NDM}}$ _like and $b l a_{\text {IMP_like }}(8.33 \%)$ genes encoding for ESBLs and carbapenemases. The resistance to non- $\beta$-lactam antibiotics was ascertained to the following markers: PMQR (QnrS - 4.16\%); sulfonamides (Sul1-75\%, Sul2$4.16 \%$ ); aminoglycosides (aac3Ia $-4.16 \%$ ); tetracyclines (tetA - $25 \%$, tetC - $15 \%$ ) (Table 2 ).

\section{Discussion}

This study investigated for the first time the AR features of cultivable microbiota of four lowland salted lakes of natural origin located in two counties from the southern region of Romania, namely Buzău and Brăila.

We observed an ubiquitary presence of Enterococcus spp. isolates, indicating the presence of chronic fecal pollution in all analyzed lakes (Table 1). Moreover, the E. faecalis strains isolated from Salty lake Câineni proved to be resistant to vancomycin (Van A) and erythromycin (ermA), exhibiting ARGs mostly found in clinical isolates. Enterococci are known to acquire relatively easy AR and to diseminate the ARGs to other species [29]. To date, nine distinct vancomycin resistance clusters have been described in enterococci (vanA, vanB, vanC, vanD, vanE, vanG, vanL, vanM and vanN), the vanA cluster being the most common mediator of vancomycin resistance in enterococci. Multidrug-resistant (MDR) and vancomycin-resistant Enterococcus (VRE) are now commonly isolated from clinical samples, sewage, aquatic enviroments, agricultural run-off and animal sources, which indicates their ability to enter the human food chain. VRE threatens to compromise the effective treatment of infections caused by these MDR bacteria, particularly in seriously ill patients who may need 
Table 2 The ARGs and antibiotic susceptibility profiles of the analysed GNR distributed by the isolation sources

\begin{tabular}{|c|c|c|c|c|c|c|c|c|c|c|c|c|c|c|c|c|c|c|c|c|}
\hline \multirow{2}{*}{$\begin{array}{l}\text { Strain } \\
\text { code }\end{array}$} & \multirow[t]{2}{*}{ Species } & \multirow{2}{*}{$\begin{array}{l}\text { Isolation } \\
\text { source }\end{array}$} & \multicolumn{10}{|l|}{ ARGs } & \multicolumn{8}{|c|}{ Antibiotic resistance profiles } \\
\hline & & & NDM & IMP & $\begin{array}{l}\text { CTX- } \\
M\end{array}$ & QnrS & Sul1 & Sul2 & TetC & TetA & aac3la & $\operatorname{lnt}$ & $\mathrm{KZ}$ & CXM & CRO & CAZ & ATM & TIC & TE & K \\
\hline P1 1.6 & S. marcescens & Balta Albă & & & $x$ & & $x$ & & & & & $x$ & $x$ & $x$ & & & & $x$ & & \\
\hline P1 1.7 & $\begin{array}{l}\text { K. } \\
\text { pneumoniae }\end{array}$ & Balta Albă & & & & & & & & & $x$ & $x$ & & $x$ & & & & $x$ & & $x$ \\
\hline P1 1.8 & K. oxytoca & Balta Albă & & & $x$ & & $x$ & & & & & & & & & & & $x$ & & $x$ \\
\hline P1 1.9 & E. kobei & Balta Albă & & $x$ & & & $x$ & & & & & $x$ & & & & & & $x$ & & \\
\hline P2 2.6 & $\begin{array}{l}\text { A. } \\
\text { calcaoceticus }\end{array}$ & Jirlău & & & $x$ & & $x$ & & & & & $x$ & $x$ & $x$ & $x$ & $x$ & $x$ & $x$ & & \\
\hline P2 2.7 & E. ludwigii & Jirlău & & & & & $x$ & & & & & & $x$ & & & & & $x$ & & \\
\hline P2 2.8 & E. cloacae & Jirlău & & & $x$ & $x$ & $x$ & & & & & $x$ & $x$ & & & & & $x$ & & \\
\hline P2 2.9 & E. coli & Jirlău & & & $x$ & & $x$ & & & & & $x$ & X & $x$ & & & & $x$ & & \\
\hline P2 2.10 & E. coli & Jirlău & & & $x$ & & & & & $x$ & & $x$ & & $X$ & & & & $X$ & $x$ & X \\
\hline P2 2.11 & E. coli & Jirlău & $x$ & & & & $x$ & & & & & $x$ & & $x$ & & & & $x$ & & $x$ \\
\hline P3 3.6 & E. coli & Câineni & & & $x$ & & & & $x$ & & & $x$ & & $x$ & & & & $x$ & $x$ & $x$ \\
\hline P3 3.7 & $\begin{array}{l}R \text {. } \\
\text { ornithinolytica }\end{array}$ & Câineni & & & & & $x$ & & & & & $x$ & & $x$ & & & & $x$ & & \\
\hline P3 3.8 & E. coli & Câineni & & & & & & & & $x$ & & $x$ & & $x$ & & & & $x$ & $x$ & $X$ \\
\hline P3 3.9 & E. coli & Câineni & $x$ & & & & $x$ & $x$ & $x$ & & & $x$ & & $x$ & & & & $x$ & $x$ & $X$ \\
\hline P3 3.10 & E. coli & Câineni & & & & & $x$ & & & $x$ & & $x$ & & & & & & $x$ & & \\
\hline P3 3.11 & E. hermannii & Câineni & & & & & $x$ & & & & & $x$ & & & & & & $x$ & & \\
\hline P4 4.6 & K. oxytoca & Amara & & & $x$ & & $x$ & & $x$ & & & $x$ & $x$ & & & & & $x$ & $x$ & \\
\hline P4 4.7 & E. cowanii & Amara & & & & & $x$ & & & $x$ & & & & & & & & $x$ & & \\
\hline P4 4.8 & S. rubidaea & Amara & & & & & $x$ & & & $x$ & & & $x$ & $x$ & & & & $x$ & & $x$ \\
\hline P4 4.9 & E. coli & Amara & & & & & & & & & & $x$ & & $x$ & & & & $x$ & & \\
\hline P4 4.10 & P. ananatis & Amara & & & & & $x$ & & & & & $x$ & $x$ & $x$ & & & & $x$ & & $x$ \\
\hline P4 4.11 & H. alvei & Amara & & & $x$ & & $x$ & & & & $x$ & $x$ & $x$ & $x$ & $x$ & & & $x$ & & \\
\hline P 2.12 & E. cloacae & Jirlău & & & & & & & & & & $x$ & $x$ & $x$ & & & & $x$ & & $x$ \\
\hline P.2.13 & E. coli & Jirlău & & & & & & & & & & $x$ & & & & & & $x$ & & $x$ \\
\hline
\end{tabular}

treatment with vancomycin where other antibiotics have failed [30]. The VRE conjugative transposons can transfer vancomycin resistance to Staphylococcus aureus, streptococci and lactobacilli. Historically, the vancomycin use was also coupled with the emergence and spread of methicillin-resistant S. aureus (MRSA) in the 1960s [31]. E. faecalis has been reported to transfer plasmids harbouring AR traits to other enterococci and to Listeria monocytogenes in wastewater treatment plants [32]. Also, E. faecium conjugative transposons can be transferred from animal to human microbiota.

The increased levels of erythromycin resistance observed in this study is also alarming, taking into account that macrolide-lincosamide-streptogramin (MLS) antibiotics constitute an alternative therapy for the treatment of insidious VRE infections [33]. Macrolide-resistant Enterococcus sp. strains have been often isolated in humans and animals $[34,35]$. Two major resistance mechanisms that cause macrolide resistance in enterococci isolates are the target modification due to the ribosomal methylase encoded by erm genes (MLSB phenotype) and the expression of efflux pumps encoded by $\operatorname{mef}(\mathrm{A} / \mathrm{E})$ and msr genes (M phenotype) [36]. Our isolates have shown the ermA genotype, affecting both macrolides and lincosamides.

Regarding the isolated GNR strains, our experimental data have shown that E. coli strains were isolated in a higher proportion in Jirlău and Câineni lakes compared to the other species (Table 2).

The emergence of GNR resistance in the aquatic environments can be associated with an increased risk to human and animal health [37-39]. Nowadays carbapenem-resistant Enterobacteriaceae are very difficult to treat especially in immunocompromised patients and these strains have also been reported in long-term care facilities [40]. Carbapenemases represent the most 


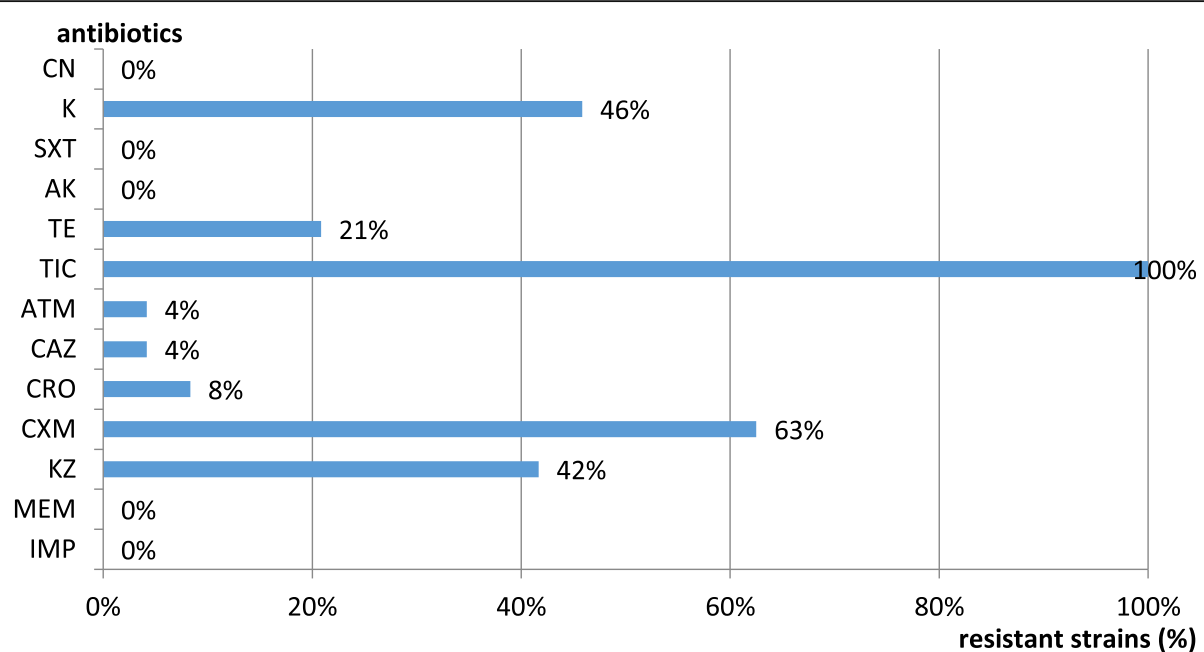

Fig. 2 The antibiotic resistance profiles of the isolated GNRs. The analyzed GNR proved to be $100 \%$ susceptible to aminoglycosides (excepting kanamycin), carbapenems, and trimethoprim/sulfamethoxazole. The GNR strains have shown $100 \%$ resistance to ticarcilin, $21 \%$ to tetracycline, $4 \%$ to aztreonam and expressed different resistance levels to cefems (between $4 \%$ and $63 \%$ )

versatile family of $\beta$-lactamases, with a breadth of spectrum unrivalled by other $\beta$-lactam-hydrolysing enzymes. They have the ability to hydrolyze penicillins, cephalosporins, monobactams, and carbapenems. The most frequently reported carbapenemases in Enterobacteriaceae isolates in decreasing order are: NDM-1 (New Delhi metallo- $\beta$-lactamases) widely distributed among Enterobacteriacae and rapidly distributed around the world, OXA-48 identified in Turkey in 2001, OXA-181, a point mutant analogue of OXA-48, reported in India KPC; IMP-1 (imipenemase) first reported in $S$. marcescens in Japan in 1991; the most frequently carbapenemases in non-fermentative GNB are the VIM type (Verona imipenemase) firstly described in Pseudomonas aeruginosa isolates, which has been identified also in Enterobacteriaceae strains [41-43].

ESBLs are a group of plasmid-mediated enzymes that are posing a major therapeutic challenge today in the treatment of hospitalized and community patients. Most of ESBLs are members of TEM, CTX-M, OXA and SHV $\beta$-lactamase families [44]. CTX-M15 (the most commonly worldwide) was predominantly revealed in humans, while CTX-M1 in farming animals. The global spread of CTX-M type enzymes also associated with quinolones resistance has become the main concern nowdays. The trimetoprim-sulphamethoxazole resistance is most frequently encoded on plasmids coexpressing ESBLs $[45,46]$. The ESBLs and carbapenemases have been reported as the major type of beta-lactams resistance mechanisms in both human and veterinary medicine among GNR. However, such resistance phenotypes were increasingly reported in the environment, which both receives and further disseminates MDR bacteria [47].
In the aquatic environments there have been demonstrated that efflux genes (tet A, B, C, D and E) are frequently detected in Enterobacterales species found in nature, humans, and animals [48]. The tet(A) gene is commonly associated with plasmids, and can be easily transferred between Gram negative bacteria [49].

In our study the integrase gene was found in more than $50 \%$ of the investigated strains $(58.33 \%)$ exhibiting a MDR phenotype. Class I integrons are capable of transferring genes responsible for resistance to $\beta$-lactam, aminoglycoside, sulfonamide and quaternary ammonium salts [50]. Several studies have correlated high class 1 integron abundance in the environmnent to anthropogenic activity. In one study, concentrations were found to be higher in aquatic environments contaminated with metals and antibiotics compared to unexposed environments. Another study showed that class 1 integrons were more abundant in detergent and antibiotic-contaminated sewage sludge and pig slurry compared to unexposed agricultural soils. The capacities of mobile integrons to disseminate among bacteria, to confer adaptive advantages to continously changing environmental conditions, and to use the gene cassettes of the environmental metagenome make them likely facilitators of environmental AR dissemination [51].

Another study performed on 108 bacterial strains isolated from eels and aquaculture ponds, revealed the presence of some ARGs (blaTEM, tetC, sull, aadA, floR and $\mathrm{qnrB}$ ) in a high percentage and also detected the class I and II integrons [52].

\section{Conclusions}

The cultivable aquatic microbiota from fishery lakes is mainly represented by enterococci and Enterobacterales strains. The source of contamination of all these lakes is 
probably the neighboring urban sewage or factories. The GNR strains exhibited high levels of $\beta$-lactam resistance mediated by ESBL and metallo- $\beta$-lactamases, accompanied with a lower resistance to the majority of all other important classes of non- $\beta$-lactam antibiotics. The majority of $E n-$ terococcus spp. isolates were resistant to macrolides and vancomycin. The high level and diversity of resistance markers, correlated with a high frequency of class 1 integrons is suggesting that this environment could act as an important reservoir of ARGs with a great probability to be horizontally transmitted to other associated species in sediments microbiota, but also to animal and human pathogens raising the potential zoonotic risk for fish consumers. Thus, the findings of this study may assist in developing strategies to avoid the spread of ARB. The limitations of the article are represented by the small number of analyzed strains, the lack of details regarding the sources of pollution with ARB or other possible characteristics that might have explained the presence of resistant microorganisms. Further studies, some of them being already underway through ongoing projects will address these limitations in the future. For now, this article represents a red flag to warn about the resistant microorganisms found in Romanian natural salted lakes included in Natura 2000 network.

\section{Methods}

\section{Sampling site and isolation of the strains}

The water samples were taken in sept. 2016 from four lowland salted lakes belonging to Natura 2000 network.
The sampling points have been represented by four lakes circumscribed to a plain area of approx. 6500 ha of water from Buzău and Brăila counties, namely: ROSCI0005 Balta Albă-Amara-Lacul Sărat Câineni-Jirlău, ROSPA0004 Balta Albă-Amara-Jirlău and the area of reservations 2.271-Balta Albă, 2.272-Balta Amara, 2.260-Lacul Jirlău (Fig. 3). The area is polluted in particular by the actions and activities of the residents such as: discharging into the lakes of the domestic residues, natural and artificial modifications of the water composition, changing the methods of cultivation of land from the traditional ones in intensive agriculture and the excessive use of fertilizers. The lakes on this site are populated with fish of different species (carp, flax, chickpea, saltpeter and slumber), which are fished and consumed, and can be carriers of ARGs. The strains were isolated from samples on a selective (EMB, McConkey) and differential culture media (blood agar) as described previously [8]. A total of 44 lowland salted lakes strains were recovered from the selective and differential culture media and identified using the MALDI-TOF-MS Bruker system: 9 from the Balta Albă lake, 11 from the Balta Amara lake, 13 from the Jirlău lake and 11 from the salty lake Câineni.

\section{Antimicrobial sensitivity test for identified strains}

The antibiotic susceptibility profiles were checked using disk diffusion method, according to Clinical and Laboratory Standards Institute (CLSI 2016 and 2017) using
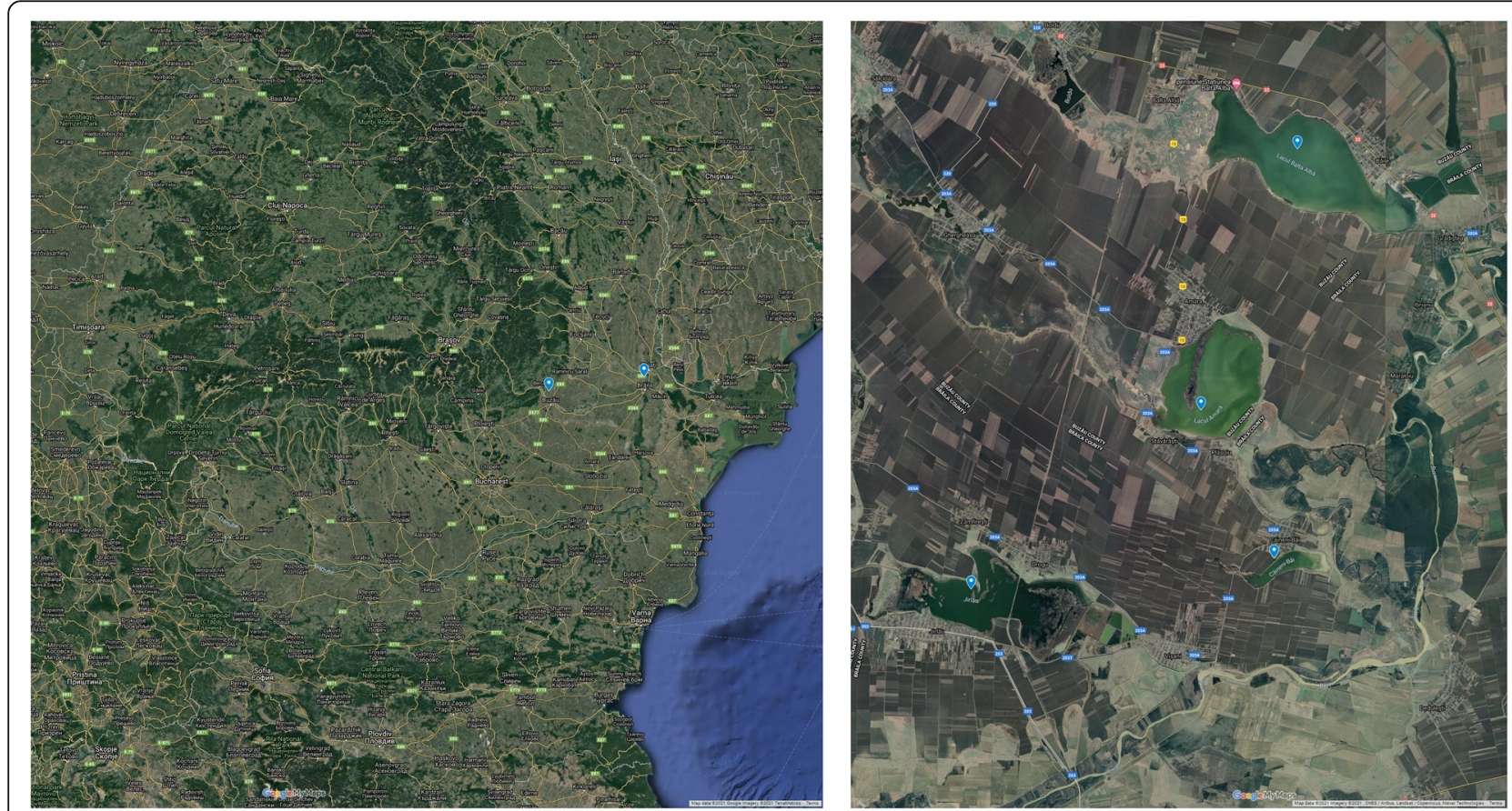

Fig. 3 The geographic location of the investigated counties and the sampled four lakes from Buzău and Brăila counties (Map source: adapted after Google Maps) 
Table 3 Primers sequences used in simplex and multiplex PCR assays for $\beta$-lactams, quinolones, and aminoglycosides and tetracycline resistance genes

\begin{tabular}{|c|c|c|c|c|}
\hline The gene & Primer & Nucleotide sequence & Amplification size and Tm & References \\
\hline bla $\mathrm{OXA-48}$ & $\begin{array}{l}\text { OXA-F } \\
\text { OXA-R }\end{array}$ & $\begin{array}{l}\text { GCGTGGTTAAGGATGAACAC } \\
\text { CATCAAGTTCAACCCAACCG }\end{array}$ & $\begin{array}{l}438 \\
52^{\circ} \mathrm{C}\end{array}$ & [53] \\
\hline$b / a_{\text {NDM }}$ & $\begin{array}{l}\text { NDM-F } \\
\text { NDM-R }\end{array}$ & $\begin{array}{l}\text { GGTTTGGCGATCTGGTTTC } \\
\text { CGGAATGGCTCATCACGATC }\end{array}$ & $\begin{array}{l}621 \\
52^{\circ} \mathrm{C}\end{array}$ & \\
\hline bla TEM & $\begin{array}{l}\text { TEM-F } \\
\text { TEM-R }\end{array}$ & $\begin{array}{l}\text { ATGAGTTTCAACATTTCG } \\
\text { TTACCAATGCTTAATCAG TG }\end{array}$ & $\begin{array}{l}861 \\
59^{\circ} \mathrm{C}\end{array}$ & [54] \\
\hline bla & $\begin{array}{l}\text { SHV-F } \\
\text { SHV-R }\end{array}$ & $\begin{array}{l}\text { GCCCTCACTCAAGGATGTAT } \\
\text { TTAGCGTTGCCAGTGCTCGA }\end{array}$ & $\begin{array}{l}888 \\
58^{\circ} \mathrm{C}\end{array}$ & [55] \\
\hline bla $a_{\mathrm{CTX}-\mathrm{M}}$ & $\begin{array}{l}\text { CTX-M-F } \\
\text { CTX-M-R }\end{array}$ & $\begin{array}{l}\text { CGCTGTTGTTAGGAAGTGTG } \\
\text { GGCTGGGTGAAGTAAGTGAC }\end{array}$ & $\begin{array}{l}730 \\
59^{\circ} \mathrm{C}\end{array}$ & {$[56]$} \\
\hline bla OXA-23 & $\begin{array}{l}\text { OXA-23-F } \\
\text { OXA-23-R }\end{array}$ & $\begin{array}{l}\text { ATGAGTTATCTATTITTGTC } \\
\text { TGTCAAGCTCTTAAATAATA }\end{array}$ & $\begin{array}{l}501 \\
52^{\circ} \mathrm{C}\end{array}$ & {$[57]$} \\
\hline bla OXA-24 & $\begin{array}{l}\text { OXA24/40-F } \\
\text { OXA24/40-R }\end{array}$ & $\begin{array}{l}\text { GCAGAAAGAAGTAAARCGGGT } \\
\text { CCAACCWGTCAACCAACCTA }\end{array}$ & $\begin{array}{l}270 \\
52^{\circ} \mathrm{C}\end{array}$ & [58] \\
\hline$b l a_{\mathrm{OXA}-51}$ & $\begin{array}{l}\text { OXA-51-F } \\
\text { OXA-51-R }\end{array}$ & $\begin{array}{l}\text { TAATGCTTTGATCGGCCTTG } \\
\text { TGGATTGCACTTCATCTTGG }\end{array}$ & $\begin{array}{l}353 \\
52^{\circ} \mathrm{C}\end{array}$ & [57] \\
\hline bla OXA-58 & $\begin{array}{l}\text { OXA-58-F } \\
\text { OXA-58-R }\end{array}$ & $\begin{array}{l}\text { AAGTATTGGGGCTTGTGCTG } \\
\text { CCCCTCTGCGCTCTACATAC- }\end{array}$ & $\begin{array}{l}599 \\
58^{\circ} \mathrm{C}\end{array}$ & [57] \\
\hline bla ${ }_{\mathrm{OXA}-143}$ & $\begin{array}{l}\text { OXA-143-F } \\
\text { OXA-143-R }\end{array}$ & $\begin{array}{l}\text { TGGATTGCACTTCATCTTGG } \\
\text { TGGCACTTTCAGCAGTTCCT }\end{array}$ & $\begin{array}{l}180 \\
58^{\circ} \mathrm{C}\end{array}$ & [59] \\
\hline bla OXA-235 & $\begin{array}{l}\text { OXA-235-F } \\
\text { OXA-235-R }\end{array}$ & $\begin{array}{l}\text { TTGTTGCCTITACTTAGTTGC } \\
\text { CAAAATTITAAGACGGATCG }\end{array}$ & $\begin{array}{l}700 \\
58^{\circ} \mathrm{C}\end{array}$ & [59] \\
\hline$b l a_{1 \mathrm{MP}}$ & $\begin{array}{l}\text { IMP-F } \\
\text { IMP-R }\end{array}$ & $\begin{array}{l}\text { GGAATAGAGTGGCTTAAYTCTC } \\
\text { GGTTTAAYAAAACAACCACC }\end{array}$ & $\begin{array}{l}232 \\
52^{\circ} \mathrm{C}\end{array}$ & {$[58]$} \\
\hline blavim-2 & $\begin{array}{l}\text { VIM }-2-F \\
\text { VIM-2-R }\end{array}$ & $\begin{array}{l}\text { GATGGTGTTGGTCGCATA } \\
\text { CGAATGCGCAGCACCAG }\end{array}$ & $\begin{array}{l}800 \\
52^{\circ} \mathrm{C}\end{array}$ & {$[58]$} \\
\hline QnrA & $\begin{array}{l}\text { QnrAm-F } \\
\text { QnrAm-R }\end{array}$ & $\begin{array}{l}\text { AGA GGA TाT CTC ACG CCA GG } \\
\text { TGC CAG GCA CAG ATC TTG AC }\end{array}$ & $\begin{array}{l}60^{\circ} \mathrm{C} \\
580\end{array}$ & This study \\
\hline QnrB & $\begin{array}{l}\text { QnrBm-F } \\
\text { QnrBm-R }\end{array}$ & $\begin{array}{l}\text { GGM ATH GAA ATT CGC CAC TG } \\
(M=A \text { or } C, H=A \text { or } C \text { or } T \\
\text { GGM ATH GAA ATT CGC CAC TG } \\
(Y=C \text { or } T)\end{array}$ & $\begin{array}{l}60^{\circ} \mathrm{C} \\
264\end{array}$ & \\
\hline Qnrs & $\begin{array}{l}\text { QnrS-F } \\
\text { QnrS-R }\end{array}$ & $\begin{array}{l}\text { GCAAGTTCATTGAACAGGGT TCT } \\
\text { AAACCGTCGAGTTCGGCG }\end{array}$ & $\begin{array}{l}428 \\
60{ }^{\circ} \mathrm{C}\end{array}$ & \\
\hline aac3la & $\begin{array}{l}\text { aac-3-laF } \\
\text { aac3IAR }\end{array}$ & $\begin{array}{l}\text { ATGGGCATCATTCGCACA } \\
\text { TCTCGGCTTGAACGAATTGT }\end{array}$ & $59^{\circ} \mathrm{C}$ & DQ370505 \\
\hline tet $\mathrm{A}$ & $\begin{array}{l}\text { tetA-F } \\
\text { tetA-R }\end{array}$ & $\begin{array}{l}\text { GCRGCGATCTGGTTCACTCG } \\
\text { AGTCGACAGYRGCGCCGGC }\end{array}$ & $\begin{array}{l}61^{\circ} \mathrm{C} \\
164\end{array}$ & [60] \\
\hline tetB & $\begin{array}{l}\text { tetB-F } \\
\text { tetB-R }\end{array}$ & $\begin{array}{l}\text { TACGTGAATTATTGCTTCGG } \\
\text { ATACAGCATCCAAAGCGCAC }\end{array}$ & $\begin{array}{l}61{ }^{\circ} \mathrm{C} \\
206\end{array}$ & \\
\hline tet $C$ & $\begin{array}{l}\text { tetC-F } \\
\text { tetC-R }\end{array}$ & $\begin{array}{l}\text { GCGGGATATCGTCCATTCCG } \\
\text { GCGTAGAGGATCCACAGGACG }\end{array}$ & $\begin{array}{l}68^{\circ} \mathrm{C} \\
207\end{array}$ & \\
\hline tetD & $\begin{array}{l}\text { tetD-F } \\
\text { tetD-R }\end{array}$ & $\begin{array}{l}\text { GGAATATCTCCCGGAAGCGG } \\
\text { CACATTGGACAGTGCCAGCAG }\end{array}$ & $\begin{array}{l}68^{\circ} \mathrm{C} \\
187\end{array}$ & \\
\hline tetM & $\begin{array}{l}\text { tetM-F } \\
\text { tetM-R }\end{array}$ & $\begin{array}{l}\text { ACAGAAAGCTTATTATATAAC } \\
\text { TGGCGT GTCTATGATGTTCAC }\end{array}$ & $\begin{array}{l}55^{\circ} \mathrm{C} \\
171\end{array}$ & [61] \\
\hline Sul1 & $\begin{array}{l}\text { Sul1-F } \\
\text { Sul1-R }\end{array}$ & $\begin{array}{l}\text { CGGCGTGGGCTACCTGAACG } \\
\text { GCCGATCGCGTGAAGTTCCG }\end{array}$ & $\begin{array}{l}432 \\
69^{\circ} \mathrm{C}\end{array}$ & [61] \\
\hline Sul2 & $\begin{array}{l}\text { Sul2-F } \\
\text { Sul2-R }\end{array}$ & $\begin{array}{l}\text { GCGCTCAAG GCAGATGGCATT } \\
\text { GCGTITGATACCGGCACCCGT }\end{array}$ & $\begin{array}{l}293 \\
69^{\circ} \mathrm{C}\end{array}$ & \\
\hline Int & $\begin{array}{l}\text { Int-F } \\
\text { Int-R }\end{array}$ & $\begin{array}{l}\text { ATGGCCGAGCAGATCCTGCACG } \\
\text { GCCACTGCGCCGTTACCACCGC }\end{array}$ & $\begin{array}{l}899 \\
60{ }^{\circ} \mathrm{C}\end{array}$ & \\
\hline $\begin{array}{l}\text { dfrA1- } \\
\text { aadA1 }\end{array}$ & $\begin{array}{l}\text { dfrA1- } \\
\text { aadA1-F } \\
\text { dfrA1- } \\
\text { aadA1-R }\end{array}$ & $\begin{array}{l}\text { AGCATTACCCAACCGAAAGT } \\
\text { TGTCAGCAAGATAGCCAGAT }\end{array}$ & $\begin{array}{l}818 \\
60{ }^{\circ} \mathrm{C}\end{array}$ & \\
\hline
\end{tabular}


standard discs $(\mu \mathrm{g} / \mathrm{disc})$ (bioMérieux) for Enterococcus spp: penicillin (P, 10), ampicillin (AMP, 10), vancomycin (VA, 30), tetracycline (TE, 30), erythromycin (E, 15), doxycylyne (DXT, 30), levofloxacin (LEV, 15), linezolid (LZD, 30) and for different groups of Gram-negative bacteria, i.e.: cefazolin $(\mathrm{KZ}, 30)$, ticarcillin-clavulanic acid (TIC, $75+10$ ), aztreonam (ATM, 30), meropenem (MEM, 10), imipenem (IMP, 10), cefuroxime (CXM, 30), ceftriaxone $(\mathrm{CRO}, 30)$, ceftazidime $(\mathrm{CAZ}, 30)$, gentamicin $(\mathrm{CN}, 10)$, amikacin $(\mathrm{AK}, 30)$, kanamycin $(\mathrm{K}, 30)$, tetracycline (TE, 30), trimethoprim-sulfamethoxazole (SXT, $1.25+23.75$ ). After $24 \mathrm{~h}$ of incubation at $37{ }^{\circ} \mathrm{C}$, organisms were classified as sensitive (S), intermediate (I) or resistant (R) based on CLSI break points.

\section{PCR detection of the resistance genes}

The genetic support of the resistance [(carbapenemases - NDM, OXA-48,VIM-2, IMP), (ESBLs - CTX-M, TEM, SHV), plasmid-mediated quinolone resistance (PMQR) markers (QnrA, QnrB, QnrS), aminoglycosides (aac3Ia), sulphonamides (Sul1, Sul2), tetracyclines (TetA, TetB, TetC, TetD, TetM), macrolides (ermA, ermB, ermC) and class 1 integrons (Int1, drfA1-aadA1) was investigated by simplex (bla $a_{\mathrm{SHV}}, b l a_{\mathrm{OXA}-51}, b l a_{\mathrm{OXA}-58}$; tetM, aac3-a; QnrS) and multiplex PCR (bla $a_{\mathrm{OXA}-48^{+}}$ bla $a_{\mathrm{NDM}} ; \quad b l a_{\mathrm{CTX}-\mathrm{M}}+b l a_{\mathrm{TEM}} ; \quad b l a_{\mathrm{OXA}-24}+b l a_{\mathrm{OXA}-24} ;$ bla $a_{\mathrm{OXA} 143}+b l a_{\mathrm{OXA} 235} ; \quad b l a_{\mathrm{IMP}}+b l a_{\mathrm{VIM}-2} ; \quad$ QnrA + QnrB; tetA + tetB; tetC + tetD; Sul1 + Sul2) (see the sequences of the primers - Table 3), using a reaction mix of $20 \mu \mathrm{l}$ (PCR Master Mix 2x, Thermo Scientific) containing $1 \mu \mathrm{l}$ of bacterial DNA extracted using an adapted alkaline extraction method. In this purpose 1-5 colonies of each strain was resuspended in $20 \mu \mathrm{l} \mathrm{NaOH}(0.05 \mathrm{M})+$ SDS $(0.25 \%)$, the suspensions were heated at $94{ }^{\circ} \mathrm{C}$ for 15 minutes followed by the addition of $180 \mu \mathrm{l}$ of TE $1 \mathrm{x}$ buffer solution and centrifugation at 13,000 rpm, 3 minutes. The supernatant was checked by electrophoretic migration in a $1 \%$ agarose gel and $1,5 \%, 45$ minutes at $90 \mathrm{~V}$ and stained with $3.5 \mu \mathrm{g} / \mathrm{ml}$ ethidium bromide.

\footnotetext{
Abbreviations

AR: Antimicrobial resistance; JPIAMR: Joint Programme Initiative on Antimicrobial Resistance; ARGs: Antibiotic resistance genes; ARB: Antibiotic resistant bacteria; PMQR: Plasmid-Mediated Quinolone Resistance Determinants; GNR: Gram- negative rods; HGT: Horizontal Gene Transfer; MDR: Multidrug-resistant; VRE: Vancomycin-Resistant Enterococcus; MRSA: Methicillin-Resistant Staphylococcus aureus; MLS: MacrolideLincosamide-Streptogramin; NDM: New Delhi metallo- $\beta$-lactamases; IMP: Imipenemase; ESBL: Extended Spectrum $\beta$-lactamases; CLSI: Clinical and Laboratory Standards Institute
}

\section{Authors' contributions}

VL, IG, CC, MIP and MCC designed the study and corrected the manuscript; DD facilitated the collection of water samples from four fishery lakes from Buzău and Brăila counties; VCC, IS and FM performed the isolation, identification and phenotypic susceptibilities of the isolated strains, IG and CC performed the molecular analyses, GLP has contributed to the design of the study, analysis of the results, drafting and the correction of the manuscript; VL, IG, MCC and CC drafted the paper and have equally contributed to this paper as main authors.

\section{Funding}

This study was supported by the Romanian Executive Agency for Higher Education, Research, Development and Innovation (https://uefiscdi.gov.ro/) research project PN-III-P4-ID-PCCF-2016-0114 POSCCE (RADAR) and COFUNDJPI-EC-AMR-ARMIS. The funding had no role in study design, data collection and analysis, decision to publish, or preparation of the manuscript.

\section{Availability of data and materials}

All data analyzed or generated during this study are included in this published article and its Supporting Information files. Any additional information is available from the corresponding author on reasonable request.

\section{Ethics approval and consent to participate}

The water sampling campaigned was performed with the permission of the custodian of the Balta Albă - Amara - Jirlău - Lacul Sărat Câineni Situs (ROSCI0005) (within the Natura 2000 site) and Maximilian Buzău Association permission - ing. Dobre Dumitru and respecting the "Habitats" Directive 92/ 43/EEC, the Government Emergency Ordinance no. 57/2007 on the regime of natural protected areas, conservation of natural habitats, wild flora and fauna, approved with amendments and supplements by Law no. 49/2011 (https://www.cbd.int/doc/world/ro/ro-nbsap-v3-en.pdf).

\section{Authors' information (optional)}

Not applicable

\section{Consent for publication}

Not applicable.

\section{Competing interests}

The authors declare that they have no competing interests.

\section{Author details}

${ }^{1}$ Department of Microbiology and Immunology, Faculty of Biology, University of Bucharest, Bucharest, Romania. ${ }^{2}$ Research Institute of the University of Bucharest (ICUB), Bucharest, Romania. ${ }^{3}$ Maximilian Association, Buzău, Romania. ${ }^{4}$ National Institute for Research and Development in Environmental Protection , Bucharest, Romania. ${ }^{5}$ Carol Davila University of Medicine and Pharmacy, Bucharest, Romania. ${ }^{6}$ Cantacuzino National Medico-Military Institute for Research and Development, Bucharest, Romania. ${ }^{7}$ Academy of Romanian Scientists, Bucharest, Romania.

Received: 12 March 2020 Accepted: 18 January 2021

Published online: 26 January 2021

\section{References}

1. Zhang XX, Zhang T, Fang HHP. Appl Microbiol B. 2009. 82:397 https://www. ecdc.europa.eu/en/antimicrobial-consumption/database/country-overview. Accesed at 10.06.2020;

2. Marlieke EA, de Kraker, Andrew J, Stewardson SH. Will 10 Million People Die a Year due to Antimicrobial Resistance by 2050? Plos Medicine. 2016. https://doi.org/10.1371/journal.pmed.1002184

3. Gaze WH, Zhang L, Abdouslam NA, Hawkey PM, Calvo-Bado L, Royle J, Brown $H$, Davis $S$, Kay P, Boxall AB, Wellington EM. Impacts of anthropogenic activity on the ecology of class 1 integrons and integronassociated genes in the environment. ISME J. 2011;5(8):1253-61. doi:https:// doi.org/10.1038/ismej.2011.15.

4. González-Zorn B, Escudero JA. Ecology of antimicrobial resistance: humans, animals, food and environment. Int Microbiol. 2012;15(3):101-9.

5. Rolain JM. Food and human gut as reservoirs of transferable antibiotic resistance encoding genes. Front Microbiol. 2013; 2013;4:173. doi: https:// doi.org/10.3389/fmicb.2013.00173. eCollection.

6. https://www.jpiamr.eu/download/Excerpt\%20Edition\%20JPIAMR\%2 OFuture\%20Strategy\%202020-2025.pdf.

7. https://www.ema.europa.eu/en/documents/report/sixth-esvac-report-salesveterinary-antimicrobial-agents-29-european-countries-2014_en.pdf. 
8. Sales of veterinary antimicrobial agents. in 30 European countries in 2016. Trends from 2010 to 2016 Eighth ESVAC report;

9. Baquero F, Martinez JL, Canton R. Antibiotics and antibiotic resistance in water environments. Curr Opin Biotechnol. 2008;19(3):260-5. doi:https://doi. org/10.1016/j.copbio.2008.05.006.

10. Bergeron S, Boopathy R, Nathaniel R, Corbin A, La Fleur G. Presence of antibiotic resistant bacteria and antibiotic resistance genes in raw source water and treated drinking water. International Biodeterioration Biodegradation. 2015;102:370-4. https://doi.org/10.1016/j.ibiod.2015.04.017.

11. Kümmerer K. Antibiotics in the aquatic environment-a review-part I. Chemosphere. 2009;75(4):417-34. doi:https://doi.org/10.1016/j. chemosphere.2008.11.086.

12. Kim S, Aga DS. Potential ecological and human health impacts of antibiotics and antibiotic-resistant bacteria from wastewater treatment plants. J Toxicol Environ Health B Crit Rev. 2007;10(8):559-73. doi:https://doi.org/10.1080/ 15287390600975137

13. Alrhmoun M. Hospital wastewaters treatment: upgrading water systems plans and impact on purifying biomass. Environmental Engineering. Université de Limoges, 2014. English. ffNNT :2014LIMO0042ff. fftel$01133490 \mathrm{f}$.

14. Karkman A, Johnson TA, Lyra C, Stedtfeld RD, Tamminen M, Tiedje JM, Virta M. High-throughput quantification of antibiotic resistance genes from an urban wastewater treatment plant. FEMS Microbiol Ecol. 2016;92(3):fiw014. doi:https://doi.org/10.1093/femsec/fiw014.

15. Rizzo L, Manaia C, Merlin C, Schwartz T, Dagot C, Ploy MC, Michael I, Fatta-Kassinos D. Urban wastewater treatment plants as hotspots for antibiotic resistant bacteria and genes spread into the environment: A review. Sci Total Environ. 2013;447:345-60. https://doi.org/10.1016/j. scitotenv.2013.01.032.

16. Krishnasamy S, Vijayan JV, Ramya S, Govindaraj D, Indumathi MN. Antibiotic usage, residues and resistance genes from food animals to human and environment: An Indian scenario. JEnviron Chem Eng. 2020;8(1):102221. https://doi.org/10.1016/j.jece.2018.02.029.

17. Amarasiri M, Sano D, Suzuki S. Understanding human health risks caused by antibiotic resistant bacteria (ARB) and antibiotic resistance genes (ARG) in water environments: Current knowledge and questions to be answered. Critical Reviews in Environmental Science Technology. 2020;50:19. DOI: https://doi.org/10.1080/10643389.2019.1692611. 2016-2059.

18. Gilmore MS, Clewell DB, Ike $Y$ et al, editors. Boston: Massachusetts Eye and Ear Infirmary. Enterococci: From Commensals to Leading Causes of Drug Resistant Infection; 2014

19. Semedo-Lemsaddek T, Pedroso N, Verdade L, Oliveira M. Otter fecal enterococci as general indicators of antimicrobial resistance dissemination in aquatic environments. Ecol Ind. 2018;85. https://doi.org/10.1016/j.ecolind. 2017.11.029

20. Picão RC, Poirel L, Demarta A, Silva CS, Corvaglia AR, Petrini O, Nordmann P. Plasmid-mediated quinolone resistance in Aeromonas allosaccharophila recovered from a Swiss lake. J Antimicrob Chemother. 2008;62(5):948-50.

21. Ma J, Liu JH, Lv L, Zong Z, Sun Y, Zheng H, Chen Z, Zeng ZL. Characterization of extended-spectrum $\beta$-lactamase genes found among Escherichia coli isolates from duck and environmental samples obtained on a duck farm. Appl Environ Microbiol. 2012;78(10):3668-73.

22. Sørum H. Antimicrobial drug resistance in fish pathogens. In: Aarestrup FM, editor. Antimicrobial Resistance in Bacteria of Animal Origin. Washington, DC, USA: American Society for Microbiology Press; 2006. pp. 213-38. (Chap. 13).

23. Aminov RI. Horizontal Gene Exchange in Environmental Microbiota. Front Microbiol. 2011;2:158.

24. Munteanu C. Nămolul Therapeutic. Romania: Ed. Balnearñ, Bucharest; 2012. pp. 43-106

25. Gâştescu P. Lacurile din România. Edit. Academiei Republicii Socialiste România Bucureşti. 1971;46:47, 316-27.

26. Moldoveanu M, Florescu L, Parpală L, Cojoc R, Enache M. ROMANIAN Salt Lakes: Some physical-chemical features and composition of biological communities. Muzeul Olteniei Craiova. Oltenia. Studii şi comunicări. Ştiințele Naturii. 2015;31(1):1454-6914

27. Păceşilă I, Cojoc R, Enache M. Evaluation of Halobacterial Extracellular Hydrolytic Activities in Several Natural Saline and Hypersaline Lakes from Romania. British Biotechnology Journal. 2014;4(5):541-50.

28. Lazăr V, Curutiu C, Ditu LM, Holban A, Gheorghe I, Marinescu F, llie M, Ivanov A, Dobre D, Chifiriuc MC. Physico-Chemical and Microbiological
Assessment of Organic Pollution in Plain Salty Lakes from Protected Regions. Journal of Environmental Protection. 2017;8(12), DOl:https://doi. org/10.4236/jep.2017.812091.

29. Kühn S, Iversen A, Burman Lg. Olsson-Liljequist B.et all. Epidemiology and ecology of enterococci, with special reference to antibiotic resistant strains, in animals, humans and the environment. Int J Antimicrob Agents. 2008;14:337-42.

30. Marcinek H, Wirth R, Muscholl-Silberhorn A, Gauer M. Enterococcus faecalis gene transfer under natural conditions in municipal sewage water treatment plants. Appl Environ Microbial. 1998;64:626-32.

31. LukáOvá J, Ustáâkováacta A. Enterococci, Antibiotic Resistance VET. BRNO,2003;72: 315-323.

32. Miller WR, Munita JM, Arias CA. Mechanisms of antibiotic resistance in enterococci. Expert Rev Anti Infect Ther. 2014;12(10):1221-36. doi:https://doi. org/10.1586/14787210.2014.956092

33. Portillo A, Ruiz-Larrea F, Zarazaga M, Alonso A, Martinez JL, Torres C. Macrolide Resistance Genes in Enterococcus spp. Antimicrob Agents Chemother. 2000;44(4):967-71.

34. Barbosa J, Ferreira V, Teixeira P. Antibiotic susceptibility of enterococci isolated from traditional fermented meat products. Food Microbiol. 2009:26:527-32.

35. Jackson CR, Fedorka-Cray PJ, Barrett JB, Ladely SR. Effects of tylosin use on erythromycin resistance in enterococci isolated from swine. Appl Environ Microb. 2004;70:4205-10

36. Zou L-K, Wang H-N, Zeng B, Li J-N, Li X-T, Zhang A-Y, Zhou Y-S, Yang X, Xu C-W. Qing-Qing Xia. Erythromycin resistance and virulence genes in Enterococcus faecalis from swine in China. New Microbiol. 2011;34:73-80.

37. Alonso A, Sanchez P, Martinez JL. Environmental selection of antibiotic resistance genes. Environ Microbiol. 2001;3:1-9.

38. Kummerer K. Resistance in the environment. J Antimicrob Chemother. 2004; 54:311-20.

39. Kirby JT, Sader HS, Walsh TR, Jones RN. Antimicrobial susceptibility and epidemiology of a worldwide collection of Chryseobacterium spp.: report from the SENTRY Antimicrobial Surveillance Program (1997-2001). J Clin Microbiol. 2004;42:445-8.

40. Perez F, Van Duin D. Carbapenem-resistant Enterobacteriaceae: a menace to our most vulnerable patients. Cleve Clin J Med. 2013;80:225-33.

41. Yamamoto T, Takano T, Iwao Y, Hishinuma AJ. Emergence of NDM-1positive capsulated Escherichia coli with high resistance to serum killing in Japan. Infect Chemother. 2011;17(3):435-9.

42. Nordmann P, Naas T, Poirel L. Global spread of Carbapenemase-producing Enterobacteriaceae. Emerg Infect Dis. 2011;17(10):1791-8.

43. Djahmi N, Dunyach-Remy C, Pantel A, Dekhil M, Sotto A, Lavigne JP. Epidemiology of carbapenemase-producing Enterobacteriaceae and Acinetobacter baumannii in Mediterranean countries. Biomed Res Int. 2014; 2014:305784.

44. Coque TM, Baquero F, Canton R. Increasing prevalence of ESBL-producing Enterobacteriaceae in Europe. Euro Surveill. 2008;13(47):pii = 19044.

45. Bouchillon S, Hoban DJ, Badal R, Hawser S. Fluoroquinolone Resistance Among Gram-Negative Urinary Tract Pathogens: Global Smart Program Results, 2009-2010. Open Microbiol J. 2012;6:74-8.

46. Kader AA, Kumar A. Prevalence and antimicrobial susceptibility of extendedspectrum beta-lactamase-producing Escherichia coli and Klebsiella pneumoniae in a general hospital. Ann Saudi Med. 2005:25(3):239-42.

47. Diab M, Hamze M, Bonnet R, Saras E, Madec JY, Haenni M.Extendedspectrum beta-lactamase (ESBL) - and carbapenemase-producing Enterobacteriaceae in water sources in Lebanon.Vet Microbiol. 2018; 217:97103. doi: https://doi.org/10.1016/j.vetmic.2018.03.007.

48. Roberts MC. Update on acquired tetracycline resistance genes. FEMS Microbiol Lett. 2005;245:195e203.

49. Anderson BW, Mccauley S, Lewis GP, Liao MK. Impacts of a poultry processing plant on the diversity of Escherichia coli populations and transferability of tetracycline resistance genes in an urban stream in South Carolina. Water Air Soil Poll. 2004;225:1-17.

50. Biyela PT, Lin J, Bezuidenhout CC. The role of aquatic ecosystems as reservoirs of antibiotic resistant bacteria and antibiotic resistance genes. Water Sci Technol. 2004;50(1):45-50.

51. Berglund B. Environmental dissemination of antibiotic resistance genes and correlation to anthropogenic contamination with antibiotics. Infection Ecology Epidemiolog. 2015;5:1.

52. Lin M, Wu X, Yan Q, Ma Y, Huang L, Qin Y, Xu X. Incidence of antimicrobial resistance genes and integrons in antibiotic resistant bacteria isolated from 
eels and aquaculture ponds. Dis Aquat Organ. 2016;120(2):115-23. doi: https://doi.org/10.3354/dao03013.

53. Poirel L, Walsh TR, Cuvillier V, Nordmann P. Multiplex PCR for detection of acquired carbapenemase genes. 2011;70(1), 119-123.

54. Efrekar RF, Hosseini-Mazinani SM, Ghandili S, Hamraz M, Zamani S. PCR detection of plasmid mediated TEM, SHV and AmpC $\beta$-lactamases in community and nosocomial urinary isolates of Escherichia coli. Iranian J Biotech. 2005;3(1):48-54.

55. Naas T, Philippon L, Poirel L, Ronco E, Nordmann P. An SHV-derived extended spectrum $\beta$-lactamase in Pseudomonas aeruginosa. Antimicrob Agents Chemother. 1999:43(5):1281-4.

56. Israil A, Chifiriuc C, Palade G, Cotar A. Clinical and bacteriological aspects of bacterial infections associated to abdominal surgical emergencies. Ars Docenti Publ. House. 2013, 150

57. Woodford N, Ellington MJ, Coelho JM, Turton JF, Ward ME, Brown S, et al. Int J Antimicrob Agents. 2006;27(4):351-3.

58. Bogaerts $\mathrm{P}$, Rezende, De Castro, R, De Mendonca, Huang T-H, Denis $\mathrm{Q}$, Glupczynski Y. Journal of Antimicrob Chemother. 2013;68:1576-82.

59. Handal R, Qunibi L, Sahouri I, Juhari M, Dawodi R, Marzouqa H, Hindiyeh M. Internat Journal of Microbiol, 2017, 1-7, https://doi.org/10 1155/2017/8012104.

60. Aminov RI, Chee-Sanford JC, Garriques N, Teferedegne B, Krapac IJ, White BA, Mackie RI. Development, Validation, and Application of PCR Primers for Detection of Tetracycline Efflux Genes of Gram-Negative Bacteria. Appl Environ Microbiol. 2002;68:1786-93.

61. Marinescu F, Măruntescu L, Savin I, Lazăr V. Antibiotic resistance markers among Gram-negative isolates from wastewater and receiving rivers in South Romania. Romanian Biotechnological Letters. 2015;20(1):10055-69.

\section{Publisher's Note}

Springer Nature remains neutral with regard to jurisdictional claims in published maps and institutional affiliations.

Ready to submit your research? Choose BMC and benefit from:

- fast, convenient online submission

- thorough peer review by experienced researchers in your field

- rapid publication on acceptance

- support for research data, including large and complex data types

- gold Open Access which fosters wider collaboration and increased citations

- maximum visibility for your research: over $100 \mathrm{M}$ website views per year

At $\mathrm{BMC}$, research is always in progress.

Learn more biomedcentral.com/submissions 